\title{
IMPLEMENTASI PENDIDIKAN KARAKTER MELALUI PEMBELAJARAN DALAM MATA PELAJARAN DI SEKOLAH DASAR
}

\author{
Ibadullah Malawi *
}

\begin{abstract}
Character education has been termed as a process of nurturing values to students to have self-reliance against God, themselves, others, environment and national awareness, which are implemented on their thought, attitude, sense, speech and action based on the norms of religion, law, ethics, culture and custom. Character education at school must involve the stakeholders. The implementation of character education is carried out through launching learning experience which is rooted from building character on students. Character education is integrated classroom practice of all subjects, which can adopt some approaches, one of which is contextual approach bringing real practice in classroom. This approach can hopefully achieve not only cognitive, but also affective and psychomotor skills.
\end{abstract}

Keywords: Character Education, Values, Elementary School Classes

\begin{abstract}
Abstrak
Pendidikan karakter merupakan nilai-nilai perilaku manusia yang berhubungan dengan Tuhan Yang Maha Esa, diri sendiri, sesama manusia, lingkungan, dan kebangsaan yang terwujud dalam pikiran, sikap, perasaan, perkataan, dan perbuatan berdasarkan norma-norma agama, hukum, tata krama, budaya, dan adat istiadat. Dalam pendidikan karakter di sekolah, semua komponen (stakeholders) harus dilibatkan, termasuk komponen-komponen pendidikan itu sendiri. Implementasi pendidikan karakter di sekolah dikembangkan melalui pengalaman belajar dan proses pembelajaran yang bermuara pada pembentukan karakter dalam diri siswa. Pembentukan karakter dalam kegiatan belajar mengajar di kelas, dilaksanakan terintegrasi dalam semua mata pelajaran. Kegiatan pembelajaran dalam kerangka pengembangan karakter, dapat digunakan berbagai pendekatan. Di antaranya pendekatan kontekstual sebagai konsep belajar dan mengajar dengan mengaitkan antara materi yang diajarkan dengan situasi dunia nyata. Dengan demikian, siswa memiliki hasil yang komprehensif, tidak hanya pada tataran kognitif (olah pikir), tetapi
\end{abstract}

* Ibadullah Malawi adalah Dosen PGSD dan Kaprodi PGSD IKIP PGRI Madiun 
juga pada tataran afektif (olah hati, rasa, dan karsa), serta psikomotor (olah raga).

Kata Kunci: Pendidikan Karakter, Nilai-nilai, Pembelajaran di Sekolah Dasar

\section{A. PENDAHULUAN}

Pendidikan karakter yang bakal diterapkan di sekolah-sekolah tidak diajarkan dalam mata pelajaran khusus. Namun, pendidikan karakter yang digencarkan dan diberi perhatian khusus dalam praksis pendidikan. Salah satu kegagalan pendidikan di Indonesia karena sistem pendidikan nasional belum mempunyai kurikulum pendidikan karakter, namun hanya ada mata pelajaran tentang pengetahuan karakter (moral) yang tertuang dalam pelajaran Agama, Kewarganegaraan, dan Pancasila. Oleh karena itu, pihak sekolah dan guru memiliki peranan yang penting agar pendidikan karakter bisa dilakukan di sekolahnya sehingga para peserta didiknya memiliki sifat yang jujur, bertanggung jawab, santun, hormat, dan kasih sayang. Demikian peran serta orangtua dan lingkungan sekitar juga penting agar anak memiliki perilaku yang baik.

Djalal menyatakan bahwa hampir semua kurikulum sekolah mengajarkan soal kejujuran, memiliki moral yang baik, bertanggung jawab, tidak merusak lingkungan, dan lainnya, seperti pelajaran Agama, Ilmu Pengetahuan Alam (IPA), Pancasila, dan Matematika (Antaranews, 2010). Oleh karena itu, meskipun di dalam kurikulum pendidikan karakter tidak tercantum, asalkan guru di setiap mata pelajaran bisa mengajarkan tentang perilaku yang baik kepada anak didiknya, maka peserta didik akan memiliki perilaku yang baik didukung oleh peran dari keluarga dan lingkungan sekitar.

Lebih lanjut Djalal, mengemukakan saat ini Kemendiknas tidak mengatur tentang kurikulum apa saja yang harus ada di sekolah. Namun, pengaturan kurikulum diserahkan kepada masing-masing sekolah, sesuai dengan kompetensi pengajaran dan kelulusan siswa. Kemendiknas hanya mengatur kompetensinya saja, namun masalah kurikulum diserahkan kepada sekolah. Pendidikan karakter yang bakal diterapkan di sekolah-sekolah tidak diajarkan dalam mata pelajaran khusus. Namun, pendidikan karakter yang bakal digencarkan dan diberi perhatian khusus dalam praksis pendidikan nasional ini dilaksanakan melalui keseharian pembelajaran yang sudah berjalan di sekolah. Jadi, pendidikan karakter yang hendak diterapkan secara nasional tidak membebani kurikulum yang ada saat ini.

\section{B. PEMBAHASAN}

\section{Pentingnya Pendidikan Karakter Bagi Siswa}

Karakter bangsa merupakan aspek yang amat penting dari kualitas sumber daya manusia (SDM) karena kualitas karakter bangsa menentukan kemajuan suatu bangsa. Dari mana memulai dibelajarkannya nilai-nilai karakter bangsa? Pendidikan karakter dimulai dari pendidikan informal, dan secara paralel berlanjut pada pendidikan formal dan nonformal. Tantangan saat ini dan ke depan bagaimana kita mampu menempatkan pendidikan karakter sebagai sesuatu kekuatan bangsa. Oleh karena itu kebijakan dan implementasi pendidikan yang berbasis karakter menjadi sangat penting dan strategis dalam rangka membangun 
bangsa ini. Hal ini tentunya juga menuntut adanya dukungan yang kondusif dari pranata politik, sosial, dan budaya bangsa.

Karakteristik yang berkualitas perlu dibentuk dan dibina sejak anak memasuki usia dini. Usia dini merupakan masa kritis bagi pembentukan karakter seseorang (Malawi, 2010:3). Menurut Freud kegagalan penanaman kepribadian yang baik di usia dini ini akan membentuk pribadi yang bermasalah di masa dewasanya kelak (Muslich, 2011:35). Keberhasilan orangtua membimbing anaknya dalam mengatasi konflik kepribadian di usia dini sangat menentukan kesuksesan anak dalam kehidupan sosial di masa dewasanya. Hal ini dipertegas oleh Lickona yang mengungkapkan sepuluh tanda-tanda kehancuran zaman yang harus diwaspadai, yaitu: (1) meningkatnya kekerasan di kalangan remaja; (2) penggunaan bahasa dan kata-kata yang memburuk; (3) pengaruh peer-group yang kuat dalam tindak kekerasan; (4) meningkatnya perilaku merusak diri, seperti penggunaan narkoba, alkohol, dan seks bebas; (5) semakin kaburnya pedoman moral baik dan buruk; (6) menurunnya etos kerja; (7) semakin rendahnya rasa hormat kepada orangtua dan guru; (8) rendahnya rasa tanggung jawab individu dan warga negara; (9) membudayanya ketidakjujuran; dan (10) adanya rasa saling curiga dan kebencian di antara sesama (Muslich, 2011: 35).

Undang-undang Nomor 20 Tahun 2003 tentang Sistem Pendidikan Nasional pasal 3 menyebutkan bahwa pendidikan nasional berfungsi mengembangkan kemampuan dan membentuk karakter serta peradaban bangsa yang bermartabat dalam rangka mencerdaskan kehidupan bangsa. Pendidikan nasional bertujuan untuk berkembangnya potensi peserta didik agar menjadi manusia yang beriman dan bertakwa kepada Tuhan Yang Maha Esa, berakhlak mulia, sehat, berilmu, cakap, kreatif, mandiri, dan menjadi warga negara yang demokratis serta bertanggung jawab. Berdasarkan fungsi dan tujuan pendidikan nasional, jelas bahwa pendidikan di setiap jenjang, harus diselenggarakan secara sistematis guna mencapai tujuan tersebut. Hal tersebut berkaitan dengan pembentukan karakter peserta didik sehingga mampu bersaing, beretika, bermoral, sopan santun dan berinteraksi dengan masyarakat.

Berdasarkan hasil penelitian Akbar (Parji, 2010) kesuksesan seseorang tidak ditentukan semata-mata oleh pengetahuan dan kemampuan teknis (hard skill) saja, tetapi lebih oleh kemampuan mengelola diri dan orang lain (soft skill). Penelitian tersebut mengungkapkan bahwa kesuksesan hanya ditentukan sekitar $20 \%$ oleh hard skill dan sisanya $80 \%$ oleh soft skill. Bahkan orang-orang tersukses di dunia bisa berhasil dikarenakan lebih banyak didukung kemampuan soft skill daripada hard skill. Hal ini mengisyaratkan bahwa mutu pendidikan karakter peserta didik sangat penting untuk ditingkatkan. Karakter merupakan nilai-nilai perilaku manusia yang berhubungan dengan Tuhan Yang Maha Esa, diri sendiri, sesama manusia, lingkungan, dan kebangsaan yang terwujud dalam pikiran, sikap, perasaan, perkataan, dan perbuatan berdasarkan norma-norma agama, hukum, tata krama, budaya, dan adat istiadat.

Pendidikan karakter adalah suatu sistem penanaman nilai-nilai karakter kepada warga sekolah yang meliputi komponen pengetahuan, kesadaran atau kemauan, dan tindakan untuk melaksanakan nilai-nilai tersebut, baik terhadap Tuhan Yang Maha Esa, diri sendiri, sesama, lingkungan, maupun kebangsaan sehingga menjadi manusia insan kamil. Dalam pendidikan karakter di sekolah, semua komponen (stakeholders) harus dilibatkan, termasuk komponen-komponen 
pendidikan itu sendiri, yaitu isi kurikulum, proses pembelajaran dan penilaian, kualitas hubungan, penanganan atau pengelolaan mata pelajaran, pengelolaan sekolah, pelaksanaan aktivitas atau kegiatan kokurikuler, pemberdayaan sarana prasarana, pembiayaan, dan etos kerja seluruh warga dan lingkungan sekolah.

Terlepas dari berbagai kekurangan dalam praktik pendidikan di Indonesia, apabila dilihat dari standar nasional pendidikan yang menjadi acuan pengembangan kurikulum (KTSP), dan implementasi pembelajaran dan penilaian di sekolah, tujuan pendidikan di sekolah baik sebenarnya dapat dicapai dengan baik. Pembinaan karakter juga termasuk dalam materi yang harus diajarkan dan dikuasai serta direalisasikan oleh peserta didik dalam kehidupan sehari-hari. Permasalahannya, pendidikan karakter di sekolah selama ini baru menyentuh pada tingkatan pengenalan norma atau nilai-nilai, dan belum pada tingkatan internalisasi dan tindakan nyata dalam kehidupan sehari-hari.

Sebagai upaya untuk meningkatkan kesesuaian dan mutu pendidikan karakter, Kementerian Pendidikan Nasional mengembangkan grand design pendidikan karakter untuk setiap jalur, jenjang, dan jenis satuan pendidikan. Grand design menjadi rujukan konseptual dan operasional pengembangan, pelaksanaan, dan penilaian pada setiap jalur dan jenjang pendidikan. Konfigurasi karakter dalam konteks totalitas proses psikologis dan sosial-kultural tersebut dikelompokkan dalam: (1) olah hati (spiritual and emotional development); (2) olah pikir (intellectual development); (3) olah raga dan kinestetik (physical and kinestetic development); dan (4) olah rasa dan karsa (affective and creativity development). Pengembangan dan implementasi pendidikan karakter perlu dilakukan dengan mengacu pada grand design tersebut.

Undang-undang Nomor 20 Tahun 2003 tentang Sistem Pendidikan Nasional pasal 13 ayat 1 menyebutkan bahwa jalur pendidikan terdiri atas pendidikan formal, nonformal, dan informal yang dapat saling melengkapi dan memperkaya. Pendidikan informal adalah jalur pendidikan keluarga dan lingkungan. Pendidikan informal sesungguhnya memiliki peran dan kontribusi yang sangat besar dalam keberhasilan pendidikan. Peserta didik mengikuti pendidikan di sekolah hanya sekitar 7 jam per hari, atau kurang dari $30 \%$. Selebihnya $(70 \%)$, peserta didik berada dalam keluarga dan lingkungan sekitarnya. Jika dilihat dari aspek kuantitas waktu, pendidikan di sekolah berkontribusi hanya sebesar $30 \%$ terhadap hasil pendidikan peserta didik.

Selama ini, pendidikan informal terutama dalam lingkungan keluarga belum memberikan kontribusi berarti dalam mendukung pencapaian kompetensi dan pembentukan karakter peserta didik. Kesibukan dan aktivitas kerja orang tua yang relatif tinggi, kurangnya pemahaman orang tua dalam mendidik anak di lingkungan keluarga, pengaruh pergaulan di lingkungan sekitar, dan pengaruh media elektronik ditengarai bisa berpengaruh negatif terhadap perkembangan dan pencapaian hasil belajar peserta didik. Salah satu alternatif untuk mengatasi permasalahan tersebut adalah melalui pendidikan karakter terpadu, yaitu memadukan dan mengoptimalkan kegiatan pendidikan informal lingkungan keluarga dengan pendidikan formal di sekolah. Dalam hal ini, waktu belajar peserta didik di sekolah perlu dioptimalkan agar peningkatan mutu hasil belajar dapat dicapai, terutama dalam pembentukan karakter peserta didik.

Pendidikan karakter dapat diintegrasikan dalam pembelajaran pada setiap mata pelajaran. Materi pembelajaran yang berkaitan dengan norma atau nilai-nilai 
pada setiap mata pelajaran perlu dikembangkan, dieksplisitkan, dikaitkan dengan konteks kehidupan sehari-hari. Dengan demikian, pembelajaran nilai-nilai karakter tidak hanya pada tataran kognitif, tetapi menyentuh pada internalisasi, dan pengamalan nyata dalam kehidupan peserta didik sehari-hari di masyarakat. Kegiatan ekstra kurikuler yang selama ini diselenggarakan sekolah merupakan salah satu media yang potensial untuk pembinaan karakter dan peningkatan mutu akademik peserta didik. Kegiatan ekstra kurikuler merupakan kegiatan pendidikan di luar mata pelajaran untuk membantu pengembangan peserta didik sesuai dengan kebutuhan, potensi, bakat, dan minat mereka melalui kegiatan yang secara khusus diselenggarakan oleh pendidik dan atau tenaga kependidikan yang berkemampuan dan berkewenangan di sekolah. Melalui kegiatan ekstra kurikuler diharapkan dapat mengembangkan kemampuan dan rasa tanggung jawab sosial, serta potensi dan prestasi peserta didik.

Pendidikan karakter di sekolah juga sangat terkait dengan manajemen atau pengelolaan sekolah. Pengelolaan yang dimaksud adalah bagaimana pendidikan karakter direncanakan, dilaksanakan, dan dikendalikan dalam kegiatan-kegiatan pendidikan di sekolah secara memadai. Pengelolaan tersebut meliputi nilai-nilai yang perlu ditanamkan, muatan kurikulum, pembelajaran, penilaian, pendidik dan tenaga kependidikan, dan komponen terkait lainnya. Dengan demikian, manajemen sekolah merupakan salah satu media yang efektif dalam pendidikan karakter di sekolah. Menurut Buchori pendidikan karakter seharusnya membawa peserta didik ke pengenalan nilai secara kognitif, penghayatan nilai secara afektif, dan akhirnya ke pengamalan nilai secara nyata (Parji, 2010). Permasalahan pendidikan karakter yang selama ini ada di sekolah perlu segera dikaji, dan dicari alternatif-alternatif solusinya, serta perlu dikembangkannya secara lebih operasional sehingga mudah diimplementasikan di sekolah.

Pendidikan karakter bertujuan untuk meningkatkan mutu penyelenggaraan dan hasil pendidikan di sekolah yang mengarah pada pencapaian pembentukan karakter dan akhlak mulia peserta didik secara utuh, terpadu, dan seimbang, sesuai standar kompetensi lulusan. Melalui pendidikan karakter diharapkan peserta didik sekolah menengah pertama (SMP) mampu secara mandiri meningkatkan dan menggunakan pengetahuannya, mengkaji, dan menginternalisasi serta mempersonalisasi nilai-nilai karakter dan akhlak mulia sehingga terwujud dalam perilaku sehari-hari. Pendidikan karakter pada tingkatan institusi mengarah pada pembentukan budaya sekolah, yaitu nilai-nilai yang melandasi perilaku, tradisi, kebiasaan keseharian, dan simbol-simbol yang dipraktikkan oleh semua warga sekolah, dan masyarakat sekitar sekolah. Budaya sekolah merupakan ciri khas, karakter atau watak dan citra sekolah tersebut di mata masyarakat luas.

Sasaran pendidikan karakter adalah seluruh sekolah di Indonesia negeri maupun swasta. Semua warga sekolah, meliputi para peserta didik, guru, karyawan administrasi, dan pimpinan sekolah menjadi sasaran program ini. Sekolah-sekolah yang selama ini telah berhasil melaksanakan pendidikan karakter dengan baik dijadikan sebagai best practices, yang menjadi contoh untuk disebarluaskan ke sekolah-sekolah lainnya. Melalui program pendidikan karakter diharapkan lulusan sekolah memiliki keimanan dan ketaqwaan kepada Tuhan, berakhlak mulia, berkarakter mulia, kompetensi akademik yang utuh dan terpadu, sekaligus memiliki kepribadian yang baik sesuai norma dan budaya. Pada tataran yang lebih luas, pendidikan karakter nantinya diharapkan menjadi budaya 
sekolah. Keberhasilan program pendidikan karakter diketahui melalui pencapaian indikator oleh siswa yang tercantum pada Standar Kompetensi Lulusan, yaitu:

a. Mengamalkan ajaran agama yang dianut sesuai dengan tahap perkembangan remaja;

b. Memahami kekurangan dan kelebihan diri sendiri;

c. Menunjukkan sikap percaya diri;

d. Mematuhi aturan-aturan sosial yang berlaku dalam lingkungan yang lebih luas;

e. Menghargai keberagaman agama, budaya, suku, ras, dan golongan sosial ekonomi dalam lingkup nasional;

f. Mencari dan menerapkan informasi dari lingkungan sekitar dan sumbersumber lain secara logis, kritis, dan kreatif;

g. Menunjukkan kemampuan berpikir logis, kritis, kreatif, dan inovatif;

h. Menunjukkan kemampuan belajar secara mandiri sesuai dengan potensi yang dimilikinya;

i. Menunjukkan kemampuan menganalisis dan memecahkan masalah dalam kehidupan sehari-hari;

j. Mendeskripsikan gejala alam dan sosial;

k. Memanfaatkan lingkungan secara bertanggung jawab;

1. Menerapkan nilai-nilai kebersamaan dalam kehidupan bermasyarakat, berbangsa, dan bernegara demi terwujudnya persatuan dalam negara kesatuan Republik Indonesia;

m. Menghargai karya seni dan budaya nasional;

n. Menghargai tugas pekerjaan dan memiliki kemampuan untuk berkarya;

o. Menerapkan hidup bersih, sehat, bugar, aman, dan memanfaatkan waktu luang dengan baik;

p. Berkomunikasi dan berinteraksi secara efektif dan santun;

q. Memahami hak dan kewajiban diri dan orang lain dalam pergaulan di masyarakat; Menghargai adanya perbedaan pendapat;

r. Menunjukkan kegemaran membaca dan menulis naskah pendek sederhana;

s. Menunjukkan keterampilan menyimak, berbicara, membaca, dan menulis dalam bahasa Indonesia dan bahasa Inggris sederhana;

t. Menguasai pengetahuan yang diperlukan untuk mengikuti pendidikan menengah;

u. Memiliki jiwa kewirausahaan.

Pada tataran sekolah, kriteria pencapaian pendidikan karakter adalah terbentuknya budaya sekolah, yaitu: perilaku, tradisi, kebiasaan keseharian, dan simbol-simbol yang dipraktikkan oleh semua warga sekolah, dan masyarakat sekitar sekolah harus berlandaskan nilai-nilai tersebut.

\section{Implementasi Pendidikan Karakter di Sekolah}

Implementasi pendidikan karakter di sekolah dikembangkan melalui pengalaman belajar dan proses pembelajaran yang bermuara pada pembentukan karakter dalam diri siswa. Pembentukan karakter dalam kegiatan belajar mengajar di kelas, dilaksanakan secara integrasi dalam semua mata pelajaran. Dengan demikian, pendidikan yang dibutuhkan saat ini adalah yang dapat mengintegrasikan pendidikan karakter dengan pembelajaran sehingga dapat 
mengoptimalkan perkembangan seluruh dimensi peserta didik, yaitu: kognitif, afektif (pengembangan kepribadian dan keterampilan sosial), dan psikomotorik. Keluaran afektif berkaitan dengan nilai, perasaan, nada, sikap, emosi.

Menurut Gagne dan Bloom proses orientasi yang berujung pada kesadaran menerima dan kecondongan terhadap nilai (Nurgiantoro, 2001:24). Contoh orientasi misalnya: toleran, suka, mencintai sastra, sikap terhadap buku bacaan (berminat atau tidak), kesediaan bertanggung jawab. Tingkatan aspek ini menurut Bloom meliputi: penerimaan, penganggapan, penilaian, organisasi, dam karakterisasi nilai. Pembentukan karakter memperhatikan faktor kesadaran diri, manajemen diri, motivasi diri. Keterampilan sosial memperhatikan empati dan kemahiran sosial. Untuk memahami lebih lanjut tataran pembentukan karakter dan keterampilan sosial, berikut dikemukakan matriks inventori kecerdasan emosional dari Goleman seperti pada Gambar 1.

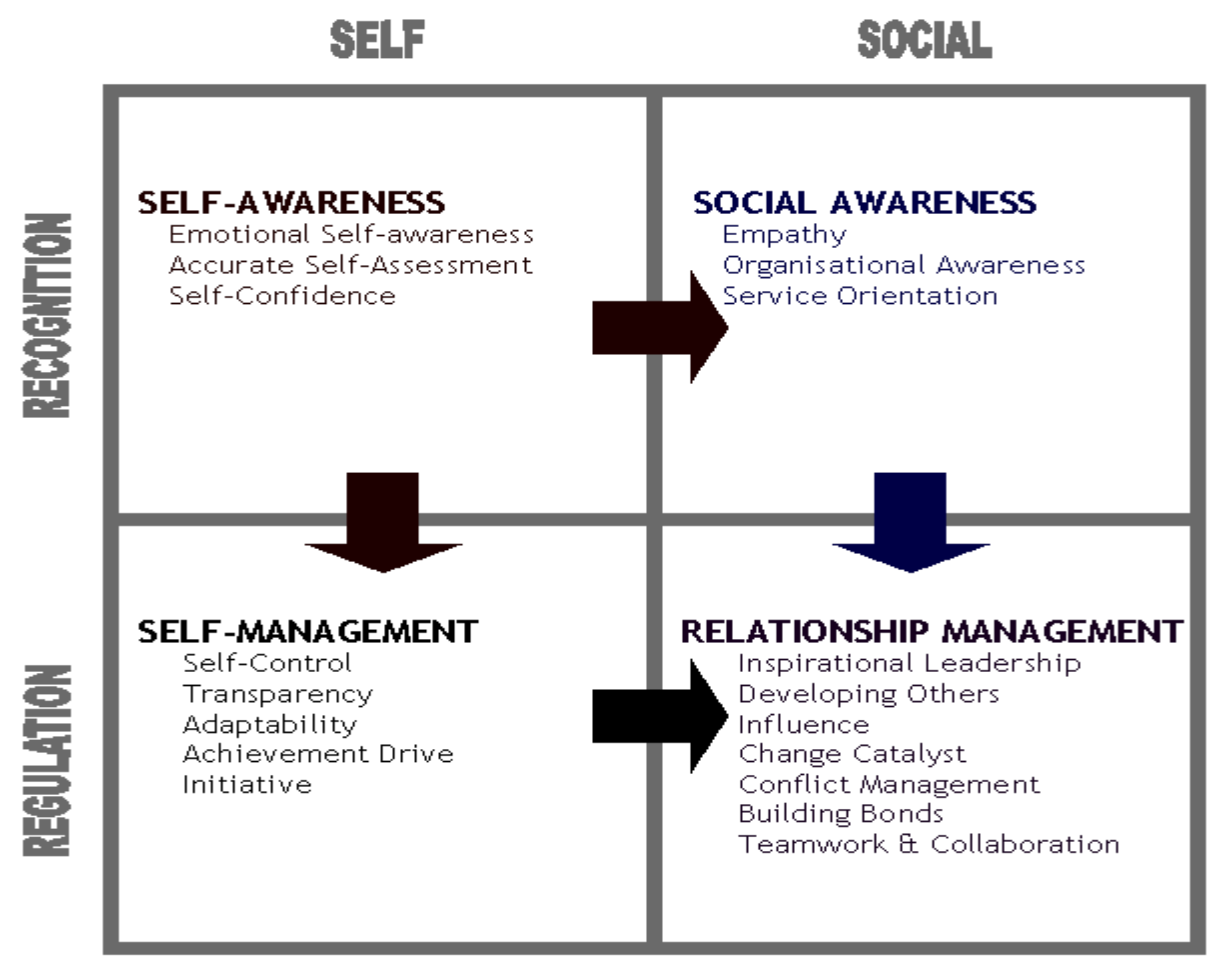

Gambar 1 Siklus Pengembangan Karakter dan Keterampilan Sosial

Perspektif lebih lengkap inventori afektif (kecerdasan emosional) tersebut dapat dilihat pada Tabel 1 .

Tabel 1 Inventori Kesadaran Emosi Model Goleman

\begin{tabular}{ll}
\hline \multicolumn{1}{c}{ Aspek Inventori } & \multicolumn{1}{c}{ Kompetensi } \\
& 1. Memiliki kesadaran emosi \\
Kesadaran diri & 2. Memiliki kemampuan menilai diri sendiri dan \\
& 3. Memiliki kepercayaan diri dalam setiap tindakan \\
\hline & 1. Mempunyai kontrol diri dalam setiap hal \\
& 2. Sadar akan amanah \\
& 3. Mempunyai ketekunan \\
& 4. Mempunyai kekuatan menyesuaikan diri \\
\hline
\end{tabular}




\begin{tabular}{|c|c|c|}
\hline \multicolumn{2}{|r|}{ Aspek Inventori } & Kompetensi \\
\hline & & 5. Mempunyai inovasi \\
\hline & & 1. Memiliki motivasi untuk mencapai cita-cita \\
\hline & & 2. Memiliki komitmen \\
\hline & Motivasi dirı & 3. Memiliki inisiatif \\
\hline & & 4. Memiliki keyakinan berhasil (optimisme) \\
\hline \multirow{13}{*}{ 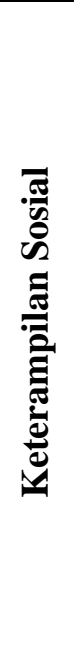 } & & 1. Memahami keadaan orang tua, guru, dan teman \\
\hline & & 2. Kemauan melavani orang lain \\
\hline & Empati & 3. Mendorong teman untuk lebih maju \\
\hline & & 4. Menghargai keberagaman \\
\hline & & 5. Kesadaran untuk membina hubungan baik \\
\hline & & 1. Keterampilan mempengaruhi orang lain \\
\hline & & $\begin{array}{l}\text { 2. Keterampilan berkomunikasi (menyampaikan dan } \\
\text { menerima informasi / gagasan, mengkritik, } \\
\text { menyanggah) }\end{array}$ \\
\hline & Kemahiran social & 3. Kepemimpinan \\
\hline & & 4. Kemampuan sebagai motor perubahan \\
\hline & & 5. Kemampuan mengatasi konflik \\
\hline & & 6. Kemampuan membuat dan melestarikan hubungan \\
\hline & & 7. Kemampuan berkolaborasi dan kerja sama \\
\hline & & 8. Kemampuan membina kekompakan kelompok \\
\hline
\end{tabular}

Adapun implikasi dalam pembelajaran di kelas, dengan memperhatikan siklus EEK dengan berorientasi pada Permendiknas Nomor 41 Tahun 2007 sebagai berikut:

\section{a. Kegiatan Pendahuluan}

Guru dalam kegiatan pendahuluan:

1) menyiapkan peserta didik secara psikis dan fisik untuk mengikuti proses pembelajaran;

2) mengajukan pertanyaan-pertanyaan yang mengkaitkan pengetahuan sebelumnya dengan materi yang akan dipelajari;

3) menjelaskan tujuan pembelajaran atau kompetensi dasar yang akan dicapai;

4) menyampaikan cakupan materi dan penjelasan uraian kegiatan sesuai silabus.

\section{b. Kegiatan Inti}

Pelaksanaan kegiatan inti merupakan proses pembelajaran untuk mencapai KD yang dilakukan secara interaktif, inspiratif, menyenangkan, menantang, memotivasi peserta didik untuk berpartisipasi aktif, serta memberikan ruang yang cukup bagi prakarsa, kreativitas, dan kemandirian sesuai dengan bakat, minat dan perkembangan fisik serta psikologis peserta didik. Kegiatan inti menggunakan metode yang disesuaikan dengan karakteristik peserta didik dan mata pelajaran, yang dapat meliputi proses eksplorasi, elaborasi dan konfirmasi.

1) Eksplorasi (Penjelajahan, identifikasi untuk memperoleh pengetahuan lebih banyak)

Guru dalam kegiatan eksplorasi:

a) melibatkan peserta didik mencari informasi yang luas dan dalam tentang topik/tema materi yang akan dipelajari dengan menerapkan prinsip alam sekitar guru dan belajar dari aneka sumber; 
b) menggunakan beragam pendekatan pembelajaran, media pembelajaran, dan sumber belajar lain;

c) memfasilitasi terjadinya interaksi antar peserta didik, serta antara peserta didik dengan guru, lingkungan, dan sumber belajar lainnya;

d) melibatkan peserta didik secara aktif dalam setiap kegiatan pembelajaran; dan

e) memfasilitasi peserta didik melakukan percobaan di laboratorium, studio, atau lapangan.

2) Elaborasi (Proses pendalaman lebih tekun, perumitan, pengawinan antar fenomena atau konsep)

Guru dalam kegiatan elaborasi:

a) membiasakan peserta didik membaca dan menulis yang beragam melalui tugas-tugas tertentu yang bermakna;

b) memfasilitasi peserta didik melalui pemberian tugas, diskusi, dan lain-lain untuk memunculkan gagasan baru baik secara lisan maupun tertulis;

c) memberi kesempatan untuk berpikir, menganalisis, menyelesaikan masalah, dan bertindak tanpa rasa takut;

d) memfasilitasi peserta didik dalam pembelajaran kooperatif dan kolaboratif;

e) memfasilitasi peserta didik berkompetisi secara sehat untuk meningkatkan prestasi belajar;

f) memfasilitasi peserta didik membuat laporan eksplorasi yang dilakukan baik lisan maupun tertulis, secara individual maupun kelompok;

g) memfasilitasi peserta didik untuk menyajikan kreasi, kerja individual maupun kelompok;

h) memfasilitasi peserta didik melakukan pameran, turnamen, festival, serta produk yang dihasilkan;

i) memfasilitasi peserta didik melakukan kegiatan yang menumbuhkan kebanggaan dan rasa percaya diri peserta didik.

3) Konfirmasi (Penegasan, pemastian, pembenaran)

Guru dalam kegiatan konfirmasi:

a) memberikan umpan balik positif dan penguatan dalam bentuk lisan, tulisan, isyarat, maupun hadiah terhadap keberhasilan peserta didik;

b) memberikan konfirmasi terhadap hasil eksplorasi dan elaborasi peserta didik melalui berbagai sumber;

c) memfasilitasi peserta didik melakukan refleksi untuk memperoleh pengalaman belajar yang telah dilakukan;

d) memfasilitasi peserta didik untuk memperoleh pengalaman yang bermakna dalam mencapai kompetensi dasar;

e) berfungsi sebagai narasumber dan fasilitator dalam menjawab pertanyaan peserta didik yang menghadapi kesulitan, dengar menggunakan bahasa yang baku dan benar;

f) membantu menyelesaikan masalah;

g) memberi acuan agar peserta didik dapat melakukan pengecekan hasil eksplorasi;

h) memberi informasi untuk bereksplorasi lebih jauh;

i) memberikan motivasi kepada peserta didik yang kurang atau belum berpartisipasi aktif. 


\section{c. Kegiatan Penutup}

Guru dalam kegiatan penutup:

1) bersama-sama dengan peserta didik dan/atau sendiri membuat rangkuman/simpulan pelajaran;

2) melakukan penilaian dan/atau refleksi terhadap kegiatan yang sudah dilaksanakan secara konsisten dan terprogram;

3) memberikan umpan balik terhadap proses dan hasil pembelajaran;

4) merencanakan kegiatan tindak lanjut dalam bentuk pembelajaran remedi, program pengayaan, layanan konseling dan/atau memberikan tugas baik tugas individual maupun kelompok sesuai dengan hasil belajar peserta didik;

5) menyampaikan rencana pembelajaran pada pertemuan berikutnya.

Jika berorientasi pada Permendiknas Nomor 41 Tahun 2007, maka seorang guru dalam pembelajaran harus melakukan proses tersebut dan menyusun Rencana Pelaksanaan Pembelajaran (RPP) dengan memasukkan karakter. Kegiatan pembelajaran dalam kerangka pengembangan karakter, guru dalam mengajar dapat menggunakan berbagai pendekatan. Di antaranya pendekatan kontekstual sebagai konsep belajar dan mengajar dengan mengaitkan antara materi yang diajarkan dengan situasi dunia nyata. Dengan demikian, siswa memiliki hasil yang komprehensif, tidak hanya pada tataran kognitif (olah pikir), tetapi juga pada tataran afektif (olah hati, rasa, dan karsa), serta psikomotor (olah raga). Pembelajaran berbasis kontekstual melibatkan tujuh komponen utama, yaitu: konstruktivisme (constructivism), bertanya (questioning), menemukan (inquiry), masyarakat belajar (learning community), pemodelan (modeling), refleksi (reflection), dan penilaian sebenarnya (authentic asessment) (Depdiknas, 2012: 26).

Pada setiap komponen memiliki karakteristik yang berbeda. Namun, tujuan yang akan dicapai adalah bagaimana membentuk pengalaman belajar siswa dengan menghubungkan antara pengetahuan yang dimilikinya dengan penerapannya dalam kehidupan mereka. Hubungan antara penerapan pembelajaran kontekstual dalam upaya membentuk nilai-nilai karakter.

1. Konstruktivisme (constructivism): Pembelajaran hendaknya dikemas menjadi proses mengontruksi bukan menerima pengetahuan. Siswa membangun sendiri pengetahuan mereka melalui keterlibatan aktif dalam proses belajar mengajar. Nilai-nilai yang dikembangkan: (a) berpikir kritis dan logis, (b) rasa ingin tahu, (c) toleransi, dan (d) bertanggung jawab;

2. Bertanya (questioning): Siswa belajar mengajukan pertanyaan tentang fenomena, belajar bagaimana menyusun pertanyaan-pertanyaan yang dapat diuji, dan belajar untuk saling bertanya. Nilai-nilai yang dikembangkan: (a) berpikir kritis dan logis, (b) rasa ingin tahu, (c) mandiri, dan (d) kreatif;

3. Menemukan (inquiry): Siswa belajar menggunakan keterampilan berpikir dan kritis saat mereka berdiskusi dan menganalisis bukti, mengevaluasi ide dan proposisi, merefleksi validasi data, memproses, membuat kesimpulan. Kemudian menemukan bagaimana mempresentasikan dan menjelaskan penemuannya, dan menghubungkan ide-ide atau teori untuk mendapatkan konsep. Nilai-nilai yang dikembangkan: (a) berpikir kritis dan logis, (b) rasa ingin tahu, (c) toleran, dan (d) kreatif; 
4. Masyarakat belajar (learning community): Semua siswa harus mempunyai kesempatan untuk bicara dan berbagi ide, mendengarkan ide siswa lain dengan cermat, dan bekerja sama untuk membangun pengetahuan dengan teman di dalam kelompoknya. Nilai-nilai yang dikembangkan: (a) demokratis, (b) peduli sosial, (c) tanggung jawab, dan (d) toleransi;

5. Pemodelan (modeling): Proses penampilan suatu contoh agar siswa berpikir, bekerja, dan belajar. Nilai-nilai yang dikembangkan: (a) rasa ingin tahu, (b) tanggung jawab, dan (c) mandiri;

6. Refleksi (reflection): Siswa menelaah suatu kejadian, kegiatan, dan pengalaman serta berpikir tentang apa yang dipelajari siswa, bagaimana merasakan dan menggunakan pengetahuan baru tersebut. Nilai-nilai yang dikembangkan: (a) rasa ingin tahu, (b) tanggung jawab, dan (c) mandiri.

7. Penilaian sebenarnya (authentic asessment): Siswa dapat mendemonstrasikan kemampuannya untuk menyelesaikan tugas-tugas, memecahkan masalah, atau mengekspresikan pengetahuannya dengan cara mensimulasikan situasi yang dapat ditemani di dalam dunia nyata di luar lingkungan sekolah. Nilainilai yang dikembangkan: (a) jujur, (b) tanggung jawab, (c) menghargai karya dan prestasi orang lain, dan (d) disiplin.

Pembelajaran dengan kontekstual mencakup beberapa strategi, yaitu: (1) pembelajaran berbasis masalah; (2) pembelajaran kooperatif; (3) pembelajaran berbasis proyek; (4) pembelajaran pelayanan; dan (5) pembelajaran berbasis kerja. Kelima strategi tersebut dapat memberikan pengembangan karakter siswa.

\section{PENUTUP}

Pendidikan karakter merupakan satu kesatuan program dalam kurikulum sekolah. Dengan demikian, setiap sekolah mengembangkan karakter sebagai satu kesatuan kegiatan pendidikan di sekolah. Nilai-nilai yang dimaksud di antaranya religius, jujur, toleransi, disiplin, kerja keras, kreatif, mandiri, demokratis, rasa ingin tahu, semangat kebangsaan, cinta tanah air, menghargai prestasi, komunikatif, cinta damai, gemar membaca, peduli sosial dan lingkungan, serta tanggung jawab. Nilai-nilai tersebut tidak diajarkan sebagai mata pelajaran tertentu tetapi diintegrasikan pada setiap pembelajaran maupun kegiatan pengembangan diri. Strategi penyampaiannya tidak bersifat informatif tetapi lebih bersifat keteladanan. Pendidik sangat menentukan keberhasilan pengembangan nilai-nilai karakter di sekolah. 


\section{DAFTAR RUJUKAN}

Anderson, L. W., dan Krathwohl, D. R. 2001. A Taxonomy for Learning, Teaching and Assessing: A Revision of Bloom's Taxonomy of Educational Objectives. New York: Longman.

Djalal, F. 2010. Peningkatan Profesionalisme Guru dan Daya Saing Bangsa melalui Pendidikan yang Berkarakter dan Bermutu (Online). (http://m.antaranews.com, diakses 18 Agustus 2010).

Kemendiknas. 2010. Panduan Penerapan Pendidikan Karakter. Jakarta: Pusat Kurikulum.

Malawi, I. 2010. Perkembangan Peserta Didik. Madiun: IKIP PGRI MADIUN.

Muslih, M. 2009. KTSP: Pembelajaran Berbasis Kompetensi dan Kontekstual. Jakarta: Bumi Aksara.

Nurgiyantoro, B. 2001. Penilaian dalam Pengajaran Bahasa dan Sastra. Yogyakarta: BPFE.

Parji. 2010. Sambutan Rektor IKIP PGRI MADIUN pada Upacara Wisuda Sarjana XL IKIP PGRI MADIUN, 2 Oktober.

Peraturan Menteri Pendidikan Nasional Nomor 41 Tahun 2007 tentang Standar Proses. Jakarta: Departemen Pendidikan Nasional Republik Indonesia.

Sulistyowati, E. 2012. Implementasi Kurikulum Pendidikan Karakter. Yogyakarta: PT Citra Aji Parama.

Undang-undang Nomor 20 Tahun 2003 tentang Sistem Pendidikan Nasional. Jakarta: Departemen Pendidikan Nasional Republik Indonesia. 